\title{
NPHS2 Gene Mutation and Polymorphisms in Indonesian Children with Steroid-Resistant Nephrotic Syndrome
}

\author{
Dedi Rachmadi1 ${ }^{*}$, Ani Melani2 ${ }^{2}$ Leo Monnens ${ }^{3}$ \\ ${ }^{1}$ Department of Child Health, Faculty of Medicine, Universitas Padjadjaran Bandung, Bandung, Indonesia \\ ${ }^{2}$ Medical Faculty, Health Research Unit, Universitas Padjadjaran Bandung, Bandung, Indonesia \\ ${ }^{3}$ Department of Pediatrics, Radboud University Medical Centre Nijmegen, Nijmegen, The Netherlands \\ Email: ${ }^{*}$ dedirachmadi@yahoo.com
}

Received 15 January 2015; accepted 6 February 2015; published 10 February 2015

Academic Editor: Carl E. Hunt, George Washington University School of Medicine and Health Sciences, USA

Copyright (C) 2015 by authors and Scientific Research Publishing Inc.

This work is licensed under the Creative Commons Attribution International License (CC BY).

http://creativecommons.org/licenses/by/4.0/

(c) (i) Open Access

\section{Abstract}

Objective: Although several NPHS2 gene mutations and polymorphisms were described and associated with clinical manifestation of steroid-resistant nephrotic syndrome (SRNS), the occurrence of these genetic abnormalities or variants appeared to be influenced by race and ethnic group. We have investigated probable mutations and variants in NPHS2 gene involved in SRNS and their association with clinical manifestations. Methods: We examined 28 children with primary SRNS who visited the pediatric nephrology division of 10 teaching hospitals in Indonesia. Molecular genetic studies of the NPHS2 gene were conducted through screenings for the exon 1, exon 2, and exon 8. The mutational analysis of NPHS2 was performed by DNA sequencing. Fisher's Exact Test was used to determine the correlation between NPHS2 polymorphisms and clinical manifestations. Results: Seven females (25\%) and 21 males (75\%) participated in the study. The mean age of the subjects with $95 \% \mathrm{CI}$ is: 7.6 (6.1 - 9.0) years while the mean age at onset of disease with 95\% CI is: 5.4 (3.9 7.0) years. Sixteen patients (57.14\%) were younger than 6 years at the onset of disease. Seventeen $(60.7 \%)$ subjects had normal eGFR, while $11(39.3 \%)$ had chronic renal insufficiency. The mean eGFR of the subjects with $95 \% \mathrm{CI}$ is: $111.4(87.7-135.1) \mathrm{ml} / \mathrm{min} / 1.73 \mathrm{~m}^{2}$. The mean systolic blood pressure with $95 \% \mathrm{CI}$ is: $117.0(108.9$ - 125.1) $\mathrm{mmHg}$ and the mean diastolic blood pressure with 95\% CI is: 77.0 (70.3 - 83.7) mmHg. We identified 6 NPHS2 polymorphisms, i.e. g. $-52 \mathrm{G}>\mathrm{T}$, c.101A $>\mathrm{G}$, g.-117C $>T$, c.288C $>T, c .954 C>T$, and c.1038A $>G$ and no mutation was found. There was no correlation between NPHS2 polymorphisms and clinical manifestations $(p>0.05)$. Conclusion: The results demonstrate no mutation of NPHS2 gene, and the 6 NPHS2 gene polymorphisms that were identified 
have no correlation with the clinical manifestation in Indonesian children with SRNS.

Keywords

Steroid-Resistant Nephrotic Syndrome, NPHS2 Gene, Polymorphism

\section{Introduction}

Steroid-resistant nephrotic syndrome (SRNS) is defined as a condition where nephrotic syndrome patients do not achieve remission after a full dose of single drug prednison therapy during the first four weeks [1] [2]. Other authors suggested a period of after 4 - 6 weeks [3] and 8 weeks of standard steroid treatment with no remission [4]. Steroid-resistant nephrotic syndrome accounts about $10 \%-15 \%$ of nephrotic syndrome in children and tends to progress to end stage-renal disease within 10 years [5]. Molecular genetic studies have demonstrated that mutations in NPHS2 gene are responsible for structurally defective podocytes or deficient basement membrane, resulting in severe proteinuria [6]-[9].

About 50 NPHS2 gene mutations and variants and/or nonsilent polymorphisms have been reported and recognized as potentially involved in proteinuria [6]. Information about NPHS2 variants for different racial and ethnic groups are lacking in terms of the variant population frequency and their association with clinical manifestations. The available data as described in HuGe review suggest that large epidemiological studies to examine the association between NPHS2 variants and nephrotic syndrome are warranted [10]. In Indonesia, knowledge on NPHS2 mutations and variants in children with SRNS is lacking. We decided to evaluate the presence of probable mutations and variants in NPHS2 gene which are involved in SRNS and their association with clinical manifestations.

\section{Materials and Methods}

Subjects were patients with steroid resistant nephrotic syndrome (SRNS) who visited the pediatric nephrology division of several educational hospitals in Indonesia. The inclusion criteria were Indonesian, aged between 1 14 years old, with primary SRNS. This study was approved by the ethical committee of the Faculty of Medicine, Universitas Padjadjaran/Dr. Hasan Sadikin General Hospital, Bandung. The definitions for nephrotic syndrome (NS) and steroid resistant nephrotic syndrome (SRNS) used were definitions as defined by the International Study of Kidney Disease in Children (ISKDC) criteria, i.e. edema, severe proteinuria, and hypoalbuminemia $(<2.5 \mathrm{~g} / \mathrm{dL})$ for NS [11] while SRNS was defined as NS patients who do not achieve remission after the fulldose single drug prednisone therapy during the first four weeks [1]. NS and SRNS were diagnosed by pediatric nephrologists or pediatricians supervised by pediatric nephrologists. Renal insufficiency was defined as an estimated glomerulo filtration rates (eGFR) of $<90 \mathrm{~mL} / \mathrm{min}$ per $1.73 \mathrm{~m}^{2}$. Data analysis was performed using SPSS $^{\mathrm{TM}}$ version 20.0. Fisher's Exact Test was used to determine the correlation between NPHS2 polymorphisms and clinical manifestations, i.e. eGFR, hematuria, and hypertension.

1) Mutation analysis

DNA was extracted and purified from peripheral blood which was collected after informed consent from the subjects was obtained in accordance with the standard protocol. These procedures were conducted at the Health Research Unit of the Faculty of Medicine, Universitas Padjadjaran, Bandung. The mutation analysis was then performed at the Laboratory of Pediatrics and Neurology of the Radboud University Medical Centre Nijmegen. The exons of the NPHS2 gene were PCR-amplified using specific primers. Three sets of primers were designed to cover the sequences of introns adjacent to each NPHS2 exon. The sequences of the forward and reverse primers, PCR conditions, and the sizes of PCR products are given in Table 1.

2) Sequence reaction protocol

We sequence a PCR product (single bright band on agarose gel), by adding to each primer: $2.5 \mathrm{uL}$ diluted PCR product $(10 \times$ diluted with MilliQ), $0.5 \mathrm{uL}$ RR-sequence mix (keep on ice containing $2.5 \times$ sequence buffer), $1.75 \mathrm{uL} 5 \times$ sequence buffer, $0.25 \mathrm{uL} 10 \mathrm{M}$ primer, and $5.0 \mathrm{uL}$ MilliQ-water. We spin the content and then put the tube(s) in a PCR machine and run the sequence program with the following instructions: $0.96^{\circ} \mathrm{C}$ for $60 \mathrm{sec} ; 1.96^{\circ} \mathrm{C}$ for $60 \mathrm{sec}$; 2 . Ramp $1^{\circ} \mathrm{C} / \mathrm{sec}$ to $50^{\circ} \mathrm{C}$; $3.50^{\circ} \mathrm{C}$ for 5 sec; 4 . Ramp $1^{\circ} \mathrm{C} / \mathrm{sec}$ to $60^{\circ} \mathrm{C} ; 5.60^{\circ} \mathrm{C}$ for $2 \mathrm{~min}$ 
Table 1. Primers and PCR conditions used in the study, NPHS2 Genbank References: NM_014625, AJ279254, NP_055440.

\begin{tabular}{cccc}
\hline Exon & Primer sequences 5, $\rightarrow \mathbf{3}$, & T anneal ( $\left.{ }^{\mathbf{C}} \mathbf{C}\right)$ & Fragment (bp) \\
\hline 1 & F: GCA GCG ACT CCA CAG GGA CT & 56 & 420 \\
R: TCC ACC TTA TCT GAC GCC CC & & 203 \\
2 & F: AGG CAG TGA ATA CAG TGA AG & 58 & 380 \\
\hline
\end{tabular}

0 sec; 6 . Go to 1.27 times; $7.15^{\circ} \mathrm{C}$ forever; 8 . End.

We add $1 \mathrm{uL} 125 \mathrm{mM}$ EDTA and $1 \mathrm{uL} 3 \mathrm{M} \mathrm{NaAc}$ and mix the content and add $30 \mathrm{uL}$ abs. EtOH.

We leave the samples at room temperature for 15 minutes and centrifuge for 30 minutes at $3000 \mathrm{~g}-4^{\circ} \mathrm{C}$, then remove the supernatant by short-spinning the opened tubes upside down on a tissue and then wash the samples by adding $35 \mathrm{uL} 70 \% \mathrm{EtOH}$ and centrifuge for 15 minutes at $1650 \mathrm{~g}-40^{\circ} \mathrm{C}$. We store the pellets at $-20^{\circ} \mathrm{C}$ until electrophoresis. Just before electrophoresis, we dissolve the pellet in $10 \mathrm{uL} \mathrm{HiDi}$, denature 1 minute at $92^{\circ} \mathrm{C}$, cool on ice and run the samples in the automatic DNA sequencer.

\section{Results}

The study population consisted of 59 Indonesian pediatric patients with primary steroid resistant nephrotic syndrome. Subjects were recruited from patients who visited the pediatric nephrology division of 10 education hospitals in several cities in Indonesia, i.e. Bandung, Jakarta, Yogyakarta, Semarang, Surabaya, Denpasar, Medan, Palembang, Makassar, and Manado. The molecular genetic studies of the NPHS2 gene were performed for all subjects but only 28 subjects were successfully screened for exon 1, exon 2, and exon 8. The other subjects and the other exons were failed to performed. The 28 subjects consisted of 7 females (25\%) and 21 males (75\%). The mean age of the subjects with 95\% CI: 7.6 (6.1 - 9.0) years while the mean age at onset of disease with 95\% CI: 5.4 (3.9 - 7.0) years. Seventeen (60.7\%) subjects had normal eGFR, while 11 (39.3\%) had chronic renal insufficiency (eGFR $<90 \mathrm{~mL} / \mathrm{min} / 1.73 \mathrm{~m}^{2}$ ). The mean eGFR of the subjects with $95 \% \mathrm{CI}: 111.4$ (87.7 - 135.1) $\mathrm{ml} / \mathrm{min} / 1.73 \mathrm{~m}^{2}$. The mean systolic blood pressure with 95\% CI: 117.0 (108.9 - 125.1) mmHg and the mean diastolic blood pressure with 95\% CI: 77.0 (70.3 - 83.7) mmHg. The clinical characteristics of the patients with NPHS2 gene polymorphisms are presented in Table 2.

The nomenclature for describing the sequence variations of NPHS2 used here was based on the reference sequence NM_014625, AJ279254, NP_055440 (Gen Bank Database). DNA sequence analysis of exon 1, exon 2, and exon 8 of the subjects did not find any mutation, but six polymorphisms were detected. In exon 1, 3 kinds of polimorfisms were revealed, i.e. g.-52G>T (heterozygous) in 4 of 28 patients (14\%), c.101A>G (homozygous) in 12 of 28 patients (43\%), and g.-117C>T (heterozygous 8 and 1 homozygous) in 9 patients (32\%). Polymorphism c.288C $>\mathrm{T}$ (heterozygous) in exon 2 was found in 4 of 28 patients (14\%), whereas in exon 8 polymorphism c.954C > T were detected in 24 patients (85.7\%), which consisted of 15 heterozygous and 9 homozygous. heterozygous c.1038A $>\mathrm{G}$ polymorphism was also found in exon 8 of 5 of 28 patients (17.8\%). The polymorphisms are presented in Table 3.

The results of the univariate analysis with Fisher's Exact Test on the correlation between NPHS2 polymorphisms and clinical manifestations, i.e. eGFR $<90\left(\mathrm{ml} / \mathrm{min} / 1.73 \mathrm{~m}^{2}\right)$, hematuria, and hypertension, were not significant (Table 4).

\section{Discussion}

Almost 50 NPHS2 gene mutations and variants and/or non-silent polymorphisms have been reported as potentially involved in structurally defective podocytes or deficient basement membrane that lacks perm-selectivity, causing proteinuria [6]. Previous studies have shown that NPHS2 gene mutations and variants were associated with different clinical features, such as early childhood onset proteinuria, rapid progression to ESRD, late onset nephrotic syndrome, and renal histology of FSGS [5] [12] [13]. In sporadic SRNS, these mutations are responsible for $10 \%$ - 30\% of diseases [13]-[17]. Most published studies on SRNS cases associated 
Table 2. Characteristics of the subject $(n=28)$.

\begin{tabular}{|c|c|c|}
\hline No & Characteristics & n (\%) \\
\hline \multirow[t]{3}{*}{1} & Sex & \\
\hline & Male & $21(75)$ \\
\hline & Female & 7 (25) \\
\hline \multirow[t]{3}{*}{2} & Hematuria & \\
\hline & $(+)$ & $8(28.6)$ \\
\hline & $(-)$ & $20(71.4)$ \\
\hline \multirow[t]{3}{*}{3} & Hypertension & \\
\hline & $(+)$ & $12(42.9)$ \\
\hline & $(-)$ & $16(57.1)$ \\
\hline \multirow[t]{4}{*}{4.} & Age (years) & \\
\hline & Mean (SD): 7.6 (3.8) & \\
\hline & Median: 7.0 & \\
\hline & Range: 2.5 - 13.9 & \\
\hline \multirow[t]{4}{*}{5.} & Age onset (years) & \\
\hline & Mean (SD): 5.4 (4.1) & \\
\hline & Median: 4.1 & \\
\hline & Range: 1.0 - 13.0 & \\
\hline \multirow[t]{4}{*}{6} & Creatinine (mg/dL) & \\
\hline & Mean (SD): 0.91 (1.07) & \\
\hline & Median: 0.6 & \\
\hline & Range: 0.2 - 6.0 & \\
\hline \multirow[t]{4}{*}{7} & eGFR (ml/min/1.73 m²) & \\
\hline & Mean (SD): 111.4 (61.2) & \\
\hline & Median: 96.5 & \\
\hline & Range: 12 - 295 & \\
\hline
\end{tabular}

Table 3. NPHS2 polymorphisms in 28 patients with steroid-resistant nephrotic syndrome.

\begin{tabular}{ccccc}
\hline Exon & Polymorphism & Effect & $\begin{array}{c}\text { Heterozygous/ } \\
\text { Homozygous }\end{array}$ & Patients (n= 28) \\
\hline 1 & g. $-52 \mathrm{G}>\mathrm{T}$ & Heterozygous & $4(14.2 \%)$ \\
1 & c.101A $>\mathrm{G}$ & p.Arg6Arg & Homozygous & $12(42.8 \%)$ \\
1 & p.Arg34Arg & Heterozygous & $8(28.5 \%)$ \\
2 & p.-117C $>\mathrm{T}$ & Homozygous & $1(3.5 \%)$ \\
8 & c. $288 \mathrm{C}>\mathrm{T}$ & p.Ser96Ser & Heterozygous & $4(14.2 \%)$ \\
8 & c.954C $>\mathrm{T}$ & p.Ala318Ala & Heterozygous & $15(53.5 \%)$ \\
& & Homozygous & $9(32.1 \%)$ \\
\hline
\end{tabular}

with biopsy-proven focal segmental glomerulosclerosis (FSGS) [5] [10] [15]. In addition, NPHS2 gene mutation studies in different populations and countries have shown that ethnicity plays an important role in disease genes [5] [18] [19]. NPHS2 412C $\rightarrow \mathrm{T}$ and 419delG gene mutations are the risk factors for SRNS in Indonesian children [20].

The result of this study shows a ratio of male and female of 3:1, which is similar to those from previous SNRS studies. The ISKDC has reported a male and female ratio of 2:1 [11]. However, Caridi et al. observed a male to female ratio of patients with an NPHS2 gene mutation of 7:2 [14]. A study about NPHS2 412C $\rightarrow$ T and 
Table 4. Correlation between NPHS2 polymorphisms and clinical manifestations in 28 patients with steroid-resistant nephrotic syndrome.

\begin{tabular}{|c|c|c|c|c|c|c|c|c|c|}
\hline \multirow[t]{2}{*}{ Polymorphisms } & \multicolumn{2}{|c|}{$\begin{array}{c}\mathrm{eGFR}<90 \\
\left(\mathrm{ml} / \mathrm{min} / 1.73 \mathrm{~m}^{2}\right)\end{array}$} & \multirow[t]{2}{*}{$\mathrm{p}^{*}$} & \multicolumn{2}{|c|}{ Hematuria } & \multirow[t]{2}{*}{$\mathrm{p}^{*}$} & \multicolumn{2}{|c|}{ Hypertension } & \multirow[t]{2}{*}{$\mathrm{p}^{*}$} \\
\hline & + & - & & + & - & & + & - & \\
\hline g. $-52 \mathrm{G}>\mathrm{T}$ & & & 1.000 & & & 1.000 & & & 0.113 \\
\hline+ & 2 & 2 & & 1 & 3 & & 0 & 4 & \\
\hline- & 9 & 15 & & 7 & 17 & & 12 & 12 & \\
\hline c. $101 \mathrm{~A}>\mathrm{G}$ & & & 0.705 & & & 0.691 & & & 0.136 \\
\hline+ & 4 & 8 & & 4 & 8 & & 3 & 9 & \\
\hline- & 7 & 9 & & 4 & 12 & & 9 & 7 & \\
\hline g. $-117 \mathrm{C}>\mathrm{T}$ & & & 1.000 & & & 0.091 & & & 0.434 \\
\hline+ & 4 & 5 & & 5 & 5 & & 3 & 7 & \\
\hline- & 7 & 12 & & 3 & 15 & & 9 & 9 & \\
\hline c. $288 \mathrm{C}>\mathrm{T}$ & & & 1.000 & & & 0.555 & & & 1.000 \\
\hline+ & 2 & 2 & & 2 & 2 & & 2 & 2 & \\
\hline- & 9 & 15 & & 6 & 18 & & 10 & 14 & \\
\hline c.954C $>\mathrm{T}$ & & & 0.355 & & & 0.311 & & & 1.000 \\
\hline+ & 10 & 12 & & 5 & 17 & & 9 & 13 & \\
\hline- & 1 & 5 & & 3 & 3 & & 3 & 3 & \\
\hline c. $1038 \mathrm{~A}>\mathrm{G}$ & & & 0.353 & & & 0.123 & & & 1.000 \\
\hline+ & 3 & 2 & & 3 & 2 & & 2 & 3 & \\
\hline- & 8 & 15 & & 5 & 18 & & 10 & 13 & \\
\hline
\end{tabular}

*Fisher's Exact Test.

419delG gene mutations in Indonesian children with SRNS concluded that male gender was risk factor for SRNS [20]. The age at onset of disease in this study is 1 to 13 years with $57 \%$ of the patients who were younger than 6years at the disease onset. Weber et al., found that NPHS2 gene mutation R138Q in SRNS patients is associated with early onset (12 \pm 3 months) [13]. Polymorphism of NPHS2 gene R229Q is associated with late-onset nephrotic syndrome [21] as well as increased risk of microalbuminuria in the general population [22]. This R229Q variant presents in approximately 4\% of Western population, encoding a protein with lower affinity for binding to nephrin [23]. About 36\% patients with SRNS exhibited progression to ESRD 5 - 6 years after onset. Aucella et al., studied 33 patients adult onset FSGS which showed that glomerular filtration rate (GFR) was in the normal range in 19 subjects and 14 patients had a variable degree of renal failure [24]. In our study, 17 (60.7\%) of the subjects had normal eGFR, while 11 (39.3\%) had chronic renal insufficiency (eGFR < 90 $\mathrm{mL} / \mathrm{min} / 1.73 \mathrm{~m}^{2}$ ). Our previous study about NPHS2 412C $\rightarrow \mathrm{T}$ and 419delG gene mutations shows that no differencein clinical manifestations is found between SRNS with mutation and SRNS without mutation, except for serum creatinin in $412 \mathrm{C} \rightarrow \mathrm{T}$ mutation [25].

This study reports the identification of 6 NPHS2 polymorphisms, i.e. g. $-52 \mathrm{G}>\mathrm{T}$, c.101A $>\mathrm{G}$, g. $-117 \mathrm{C}>\mathrm{T}$, c. $288 \mathrm{C}>\mathrm{T}$, с.954C $>\mathrm{T}$, and с.1038A $>\mathrm{G}$, in patients with clinical diagnosis of SRNS. Homozygous NPHS2 c.101A $>$ G polymorphism was found in 12 subjects, leading to p.Arg34Arg. Homozygous NPHS2 g.-117C >T was found only in 1 subject and Homozygous NPHS2 c.954C > T was found in 9 subjects, leading to p.Ala318Ala. The other NPHS2 polymorphisms were heterozygous. The NPHS2 homozygous and heterozygous polymorphisms have not been implicated in clinical manifestation of SRNS, such as decrease of GFR, hypertension and 
hematuria, in this study (Table 4).

In our study, we could not find any mutation of NPHS2 gene as causative SNRS, suggesting that NPHS2 gene mutations are not major cause of SNRS in Indonesian children. In addition, we also suggests that there is an inter-ethnic difference in the occurrence of NPHS2 gene mutations or their variants, so the 6 NPHS2 gene polymorphisms that were identified have no correlation with the clinical manifestation. The strength of our study lies in the collection of sample from multicenter of various teaching hospitals in Indonesia, while the weakness of this study is only 28 of 59 samples were successfully screened, due to limitation of time and research finance.

\section{Conclusion}

In conslusion, no mutation was found in this study; however, due to our limitations, more studies are needed. Other exons of podocin or other podocyte proteins in Indonesian children may play a role in the pathogenesis of SRNS.

\section{Acknowledgements}

We thank to Prof Bert vanden Heuvel for supervising our research with mutation analysis of NPHS2 gen that performed at The Laboratory of Pediatrics and Neurology of the Radboud University Medical Centre Nijmegen.

\section{References}

[1] Clark, A.G. and Barrat, T.M. (1999) Steroid Responsive Neprotic Syndrome. In: Barrat, T.M., Avner, E.D. and Harmon, W.E., Eds., Pediatric Nephrology, 4th Edition, Lippincott Willams \& Wilkins, Baltimore, $731-747$.

[2] Fydryk, J. and Querfeld, U. (2002) The Nephrotic Syndrome-Idiopathic Steroid Resistant Nephrotic Syndrome. In: Cochat, P., Ed., European Society for Paediatric Nephrology Handbook, ESPN, Switzerland, 259-262.

[3] Roth, K.S., Amaker, B.H. and Chan, J.C.M. (2002) Nephrotic Syndrome: Pathogenesis and Management. Pediatrics in Review, 23, 237-247. http://dx.doi.org/10.1542/pir.23-7-237

[4] Hogg, R.J., Portman, R.J., Milliner, D., Lemley, K.D., Eddy, A. and Ingelfinger, J. (2000) Evaluation and Management of Proteinuria and Nephrotic Syndrome in Children: Recommendations from a Pediatric Nephrology Panel Established at the National Kidney Foundation Conference on Proteinuria, Albuminuria, Risk, Assessment, Detection, and Elimination (PARADE). Pediatrics, 105, 1242-1249. http://dx.doi.org/10.1542/peds.105.6.1242

[5] Kitamura, A., Tsukaguchi, H., Iijima, K., Araki, J., Hattori, M., Ikeda, M., et al. (2006) Genetics and Clinical Features of 15 Asian Families with Steroid-Resistant Nephrotic Syndrome. HealthNephrology Dialysis Transplantation, 21, 3133-3138. http://dx.doi.org/10.1093/ndt/gfl347

[6] Caridi, G., Perfumo, F. and Ghiggeri, G.M. (2005) NPHS2 (Podocin) Mutations in Nephrotic Syndrome. Clinical Spectrum and Fine Mechanisms. Pediatric Research, 57, 54R-61R. http://dx.doi.org/10.1203/01.PDR.0000160446.01907.B1

[7] Niaudet, P. (2004) Genetic Form of Nephrotic Syndrome. Pediatric Nephrology, 19, 1313-1318. http://dx.doi.org/10.1007/s00467-004-1676-9

[8] Bagga, A. and Mantan, M. (2005) Nephrotic Syndrome in Children. Indian Journal of Medical Research, 122, 13-28.

[9] Antignac, C. (2002) Genetic Models: Clues for Understanding the Pathogenesis of Idiopathic Nephrotic Syndrome. Journal of Clinical Investigation, 109, 447-449. http://dx.doi.org/10.1172/JCI0215094

[10] Franceschini, N., Karl, N., Jeffrey, K., Louise, M. and Cheryl, W. (2006) NPHS2 Gene, Nephrotic Syndrome and Focal Segmental Glomerulosclerosis: A HuGE Review. Genetics in Medicine, 8, 63-75. http://dx.doi.org/10.1097/01.gim.0000200947.09626.1c

[11] International Study of Kidney Disease in Children (ISKDC) (1981) The Primary Nephrotic Syndrome in Children. Identification of Patients with Minimal Change Nephrotic Syndrome from Initial Response to Prednison. The Journal of Pediatrics, 98, 561-564. http://dx.doi.org/10.1016/S0022-3476(81)80760-3

[12] Hinkes, B., Vlangos, C., Heeringa, S., Mucha, B., Gbadegesin, R., Liu, J., et al. (2008) Specific Podocin Mutations Correlate with Age of Onset in Steroid-Resistant Nephrotic Syndrome. Journal of the American Society of Nephrology, 19, 365-371. http://dx.doi.org/10.1681/ASN.2007040452

[13] Weber, S., Gribouval, O., Esquivel, E.L., Moriniere, V., Tête, M.J., Legendre, C., et al. (2004) NPHS2 Mutation Analysis Show Genetic Heterogeneity of Steroid-Resistant Nephrotic Syndrom and Lowpost-Transplant Recurrence. Kidney International, 66, 571-579. http://dx.doi.org/10.1111/j.1523-1755.2004.00776.x

[14] Caridi, C., Berteli, R., Carrea, A., Di Duca, M., Catarsi, P., Artero, M., et al. (2001) Prevalence, Genetics, and Clinical 
Features of Patients Carrying Podocin Mutations in Steroid-Resistant Nonfamilial Focal Segmental Glomerulosclerosis. Journal of the American Society of Nephrology, 12, 2742-2746.

[15] Karle, S., Uetz, B., Ronner, V., Glaeser, L., Hildebrandt, F. and Fuchshuber, A., Members of the APN Study Group (2002) Novel Mutations in NPHS2 Are Detected in Familial as Well as Sporadic Steroid Resistant Nephritic Syndrome. Journal of the American Society of Nephrology, 13, 388-393.

[16] Caridi, G., Bertelli, R., Di Duca, M., Dagnino, M., Emma, F. and Muda, A.O. (2003) Broadening the Spectrum of Diseases Related to Podocin Mutations. Journal of the American Society of Nephrology, 14, 1278-1286. http://dx.doi.org/10.1097/01.ASN.0000060578.79050.E0

[17] Ruf, R.G., Lichtenberger, A., Karle, S.M., Haas, J.P., Anacleto, F.E., Schultheiss, M., et al., The APN Study Group (2004) Patients with Mutations in NPHS2 (Podocin) Do Not Respond to Standard Steroid Treatment of Nephrotic Syndrome. Journal of the American Society of Nephrology, 15, 722-732. http://dx.doi.org/10.1097/01.ASN.0000113552.59155.72

[18] Yu, Z.H., Ding, J., Huang, J.P., Yao, Y., Xiao, H.J., Zhang, J.J., et al. (2005) Mutations in NPHS2 in Sporadic Steroid-Resistant Nephrotic Syndrome in Chinese Children. Nephrology Dialysis Transplantation, 20, 902-908. http://dx.doi.org/10.1093/ndt/gfh769

[19] Otukesh, H., Ghazanfari, B., Fereshtehnejad, S.M., Bakhshayesh, M., Hashemi, M., Hoseini, R., et al. (2009) NPHS2 Mutations in Children with Steroid-Resistant Nephritic Syndrome. Iranian Journal of Kidney Diseases, 3, 99-102.

[20] Rachmadi, D., Hilmanto, D., Idjradinata, P. and Sukadi, A. (2011) NPHS2 Gene Mutation, Atopy and Gender as Risk Factors for Steroid-Resistant Nephrotic Syndrome in Indonesian. Paediatrica Indonesiana, 51, 272-276.

[21] Tsukaguchi, H., Sudhakar, A., Le, T.C., Nguyen, T., Yao, J., Schwimmer, J.A., Schachter, A.D., et al. (2002) NPHS2 Mutations in Late-Onset Focal Segmental Glomerulosclerosis: R229Q Is a Common Disease-Associated Allele. Journal of Clinical Investigation, 110, 1659-1666. http://dx.doi.org/10.1172/JCI0216242

[22] Pereira, A.C., Pereira, A.B., Mota, G.F., Cunha, R.S., Herkenhoff, F.L., Pollack, M.R., et al. (2004) NPHS2 R229Q Functional Variant Is Associated with Microalbuminuria in the General Population. Kidney International, 65, 10261030. http://dx.doi.org/10.1111/j.1523-1755.2004.00479.x

[23] Obeidova, H., Merta, M., Reiterova, J., Maixnerova, D., Stekrova, J., Rysava, R., et al. (2006) Genetic Basis of Nephrotic Syndrome-Review. Prague Medical Report, 107, 5-16.

[24] Aucella, F., De Bonis, P., Gatta, G., Muscarella, L.A., Vigilante, M., Di Giorgio, G., et al. (2004) Molecular Analysis of NPHS2 and ACTN4 Genes in a Series of 33 Italian Patients Affected by Adult-Onset Nonfamilial Focal Segmental Glomerulosclerosis. Nephron Clinical Practice, 99, 31-36. http://dx.doi.org/10.1159/000082864

[25] Rachmadi, D., Hilmanto, D., Idjradinata, P. and Sukadi, A. (2011) NPHS2 (412 C $\rightarrow$ T and 419delG) Gene Mutation and Their Clinical Manifestation in Indonesian Steroid-Resistant Nephrotic Syndrome. Majalah Kedokteran Bandung, 43, 193-198. http://dx.doi.org/10.15395/mkb.v43n4.69 
Scientific Research Publishing (SCIRP) is one of the largest Open Access journal publishers. It is currently publishing more than 200 open access, online, peer-reviewed journals covering a wide range of academic disciplines. SCIRP serves the worldwide academic communities and contributes to the progress and application of science with its publication.

Other selected journals from SCIRP are listed as below. Submit your manuscript to us via either submit@scirp.org or Online Submission Portal.
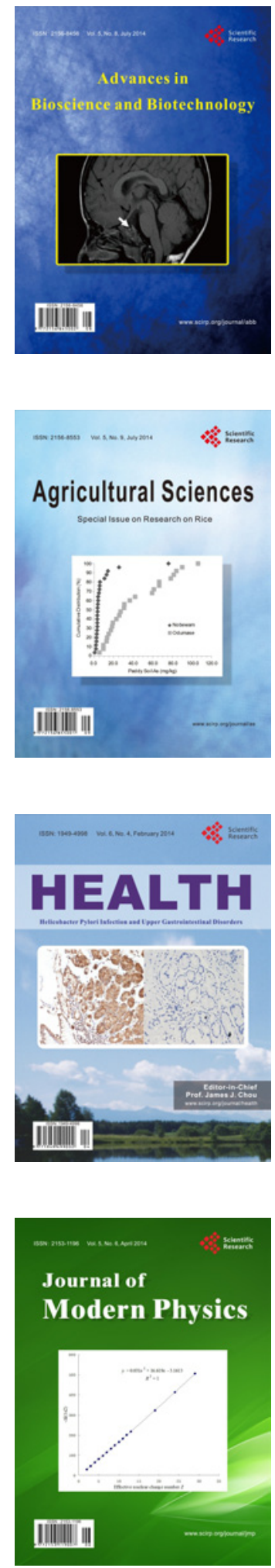
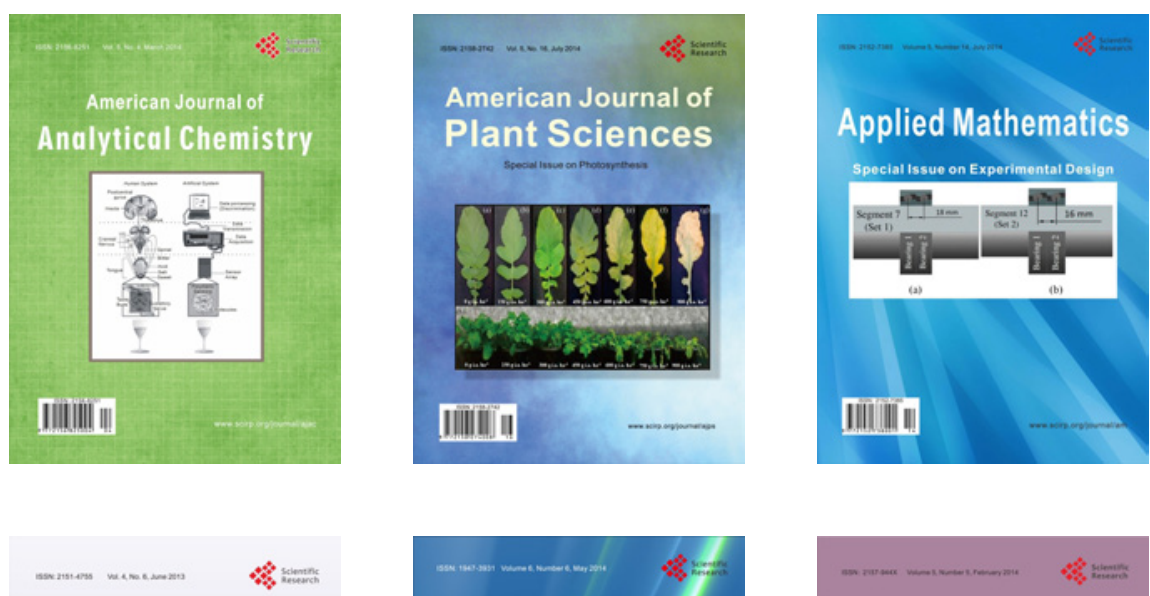

Creative Education
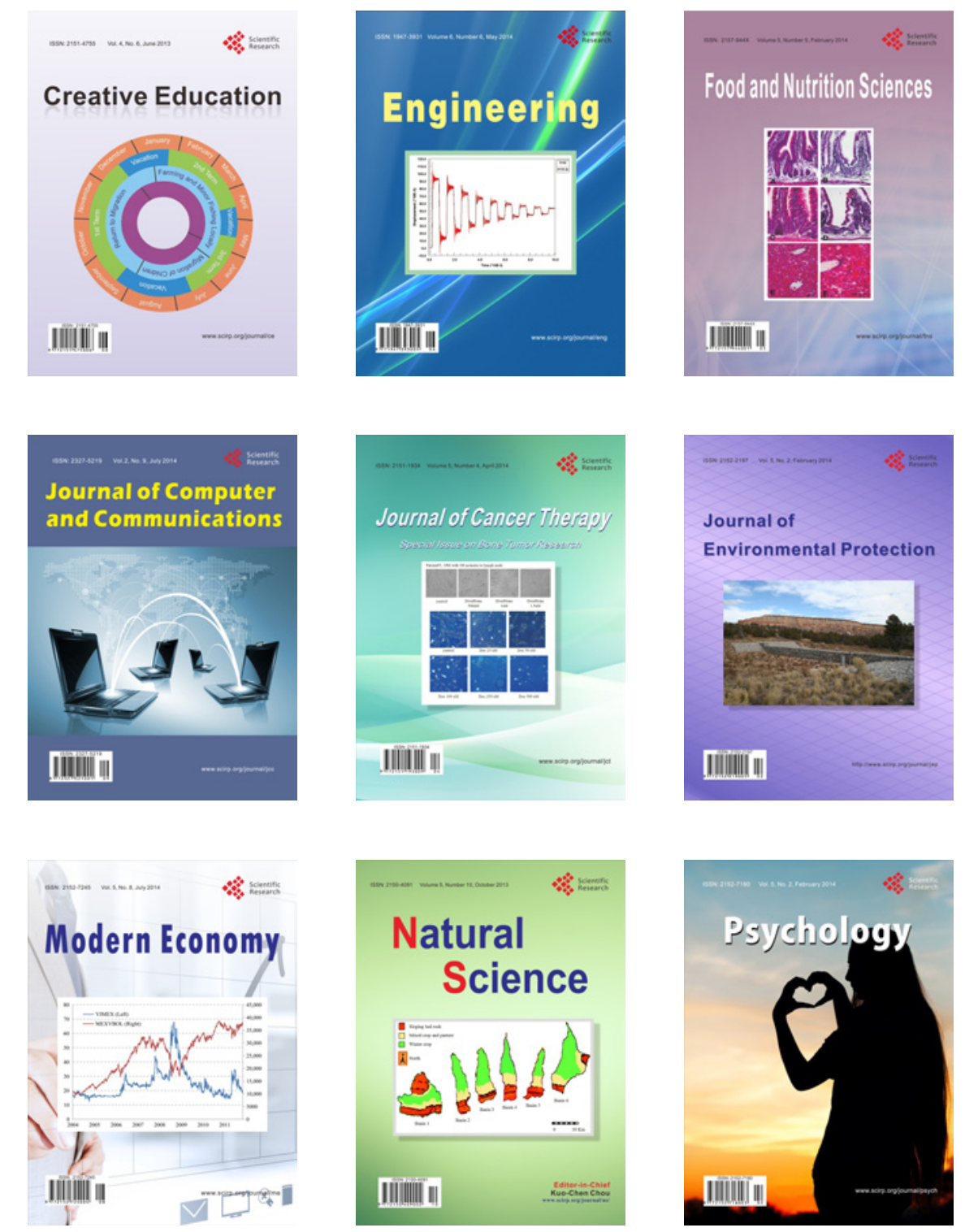